\title{
“ART AND CULTURE” LEARNING MANAGEMENT FOR STUDENTS' INCREASED ACHIEVEMENT DURING THE COVID-19 PANDEMIC
}

\author{
Anna Sophia Adham', Fitri Nur Mahmudah² \\ Education Management Department, Universitas Ahmad Dahlan, Yogyakarta, Indonesia \\ Email: annasophia639@gmail.com ${ }^{1}$, fitri.mahmudah@mp.uad.ac.id ${ }^{2}$
}

\begin{tabular}{|l|c|c|}
\hline \multicolumn{3}{|c|}{ DOI: http://doi.org/10.33650/al-tanzim.v5i1.1904 } \\
\hline Received: January 2021 & Accepted: March 2021 & Published: March 2021
\end{tabular}

\begin{abstract}
:
One of the keys to the success of learning is good management. During the Covid-19 pandemic, teachers need managerial skills for the learning process to take place. The purpose of this study is to determine the management of learning arts and culture to improve student achievement during the Covid-19 pandemic. The study employed the qualitative approach to research. Data collection techniques used were interviews, observation, and documentation. The results of this study indicate that the learning management that teachers need to do in Art and Culture is due to the characteristics, creation, communication, motivation, learning strategies, and discipline. The recommendations of this research can be used by teachers in developing culture and art learning during the Covid-19 pandemic. Hence, teachers will be able to provide learning to students, and students can attain improved skills and good learning outcomes.
\end{abstract}

Keywords: Learning Management, Achievements, The Covid-19 Pandemic

\begin{abstract}
Abstrak:
Salah satu kunci keberhasilan dari pembelajaran adalah karena ada manajemen yang baik. Pada masa pandemi covid-19, guru membutuhkan manajerial demi berlangsungnya proses pembelajaran. Tujuan penelitian ini adalah untuk mengetahui manajemen pembelajaran seni budaya untuk meningkatkan prestasi masa pandemi covid-19. Metode yang digunakan dalam penelitian ini adalah kualiatatif. Teknik pengambilan data dengan menggunakan wawancara, observasi, dan dokumentasi. Hasil penelitian ini memberikan gambaran bahwa manajemen pembelajaran yang perlu dilakukan oleh guru pada mata pelajaran seni budaya adalah dikarenakan adanya karakteristik, kreasi, komunikatif, motivasi, strategi pembelajaran, dan tata tertib. Rekomendasi penelitian ini dapat digunakan oleh guru dalam mengembangkan pembelajaran seni budaya selama pandemi covid-19. Sehingga guru mampu memberikan pembelajaran kepada para siswa dan siswa dapat meningkatkan keterampilan dan hasil belajar yang baik.
\end{abstract}

Kata Kunci: Manajemen Pembelajaran, Prestasi, Pandemi Covid-19 


\section{INTRODUCTION}

Education seeks to develop human beings, and hence the success of education depends on the human element (Molchanova \& Federation, 2019). The human element that mostly determines the success of education is the education practitioner, that is the teacher. Teachers are the spearhead of education, for they indirectly attempt to influence, foster, and develop students' abilities, intelligence, skills and morality as human beings. Art and Culture subject, in this regard, has a role in shaping and developing students' personality and fostering their intelligence.

Various counter-production behaviors today, students' impoliteness for instance, indicate the role of learning art that has not touched its essence, namely the taste and refinement of character, and has been unable to trigger the enthusiasm and reasoning power of students to be creative. In other words, there is still a problem in the implementation of art and culture learning. Research confirms that proper management of learning can create optimal learning conditions and neutralize the situation, particularly when there is a disturbance in the classroom during teaching and learning activities. Therefore, all parties need to be involved, including art teachers, carefully explore the substance and context of art learning clearly and proportionally. Thus, the goals of learning art can be achieved optimally and are relevant to the individual needs of students.

Various counter-productive behaviors as such also indicate how the role of art learning has not yet reached its essential level. Education for aesthetic expressions is still not considered important by some people and the school itself. While art and culture are still seen as a complementary subject, the teachers are carried away by wrong perceptions of educational outcomes, assuming that successful students are those who know about cultural arts. Art and Culture education is not considered both in terms of the teaching and learning process, media and teaching materials as well as other forms of assessment. The ability of teachers to empower the potential of the cultural environment and the potential of the school to support the learning of aesthetic expressions is limited.

Based on the results of research entitled "Management of Learning Cultural Arts at SMP Negeri 1 Pulokulon, Grobogan Regency", class management in learning arts and culture begins with the preparation of lesson plans which refer to the competency standards and basic competencies in the curriculum. Management in class settings is planned before the learning process, and so the student environment which is the basis of learning to be taught is prepared in advance. According to Hardiyanto (2012), art and culture education has a character in the orientation of changes in the behavior of quality students in knowledge, skills, and attitudes to respect art, and can create art creatively. In the regulation of the Government of the Republic of Indonesia Number 19 of 2005, concerning National Education Standards, art and culture learning is not only in one subject because culture itself covers all aspects of life. In the subject of arts and culture, cultural aspects are not discussed separately but are integrated with art. 
The essence of teaching and learning activities is none other than the learning activities of students in achieving a teaching. (Hasbi \& Mahmudah, 2020). Anyone will never deny that teaching and learning activities do not proceed in a vacuum, but with a meaning. It is the teacher who creates teaching and learning conditions that lead students to goals that are capable of fostering competitive moral intelligence (Sholekah \& Mahmudah, 2020). Art and culture education has a role in the personal formation of students who are harmonious with attention to the development needs of children in achieving multi intelligence. The management of learning art and culture carried out properly can create conducive classroom conditions and high achievements.

The purpose of writing this article is to determine class management in learning art and culture in an effort to improve student learning outcomes at SMP Muhammadiyah 5 Yogyakarta. The success of a learning process is measured by the achievement of students in participating in learning activities.

\section{RESEARCH METHOD}

The research approach used in this study is qualitative. Qualitative research aims to provide new theories, or strengthen existing theories. The study applies a descriptive non-experimental research, marked by the reporting of data on the research object. The research was conducted at SMP Muhammadiyah 5 Yogyakarta, Jalan Patehan Lor no. 25, Patehan Village, Kraton District, Yogyakarta. In this study, the sampling used is purposive sampling. The source of the data is the art and culture teacher.

The data collection techniques used were observations and interviews. The validity of the data in this study employed triangulation. The method of observation was a systematic observation and recording of the phenomena being investigated. This observation method was used to obtain data about geography, organizational structure and general conditions in SMP Muhammadiyaha 5 Yogyakarta. Interviews were used as a data collection technique, in which the researchers wanted to conduct a preliminary study to find problems that must be researched, and find out more about the respondents and the number of respondents. The interviews were used to find direct and concrete information from the informants regarding the information needed. Interviews were conducted with school principals, teachers and students. To get their response on the management that is enforced. Besides, this method was also used to obtain unfulfilled data through observation. Documentation is a way of collecting through written enhancements, especially in the form of archives and including books on opinions, theories, laws and others related to investigative problems. The documentation method was used to obtain data on the list of names of the administrators, management structures, and archives considered important in the research taken from SMP Muhammadiyah 5 Yogyakarta. 


\section{FINDINGS AND DISCUSSION}

In learning art and culture, a learning strategy is needed so that conditions in the classroom can be conditioned without any constraints so as to create a safe, comfortable, conducive learning environment effectively and efficiently. The rules that have been agreed upon in learning art and culture can bring out the characteristics and creations of students during class learning. Students can provide brilliant ideas in producing their best work and can improve student learning outcomes. One of the duties of the teacher is to motivate students so that the learning of cultural art becomes enthusiastic and focused, by providing interesting learning strategies. Learning cultural art will have no problem through the creation of a comfortable and conducive classroom atmosphere.

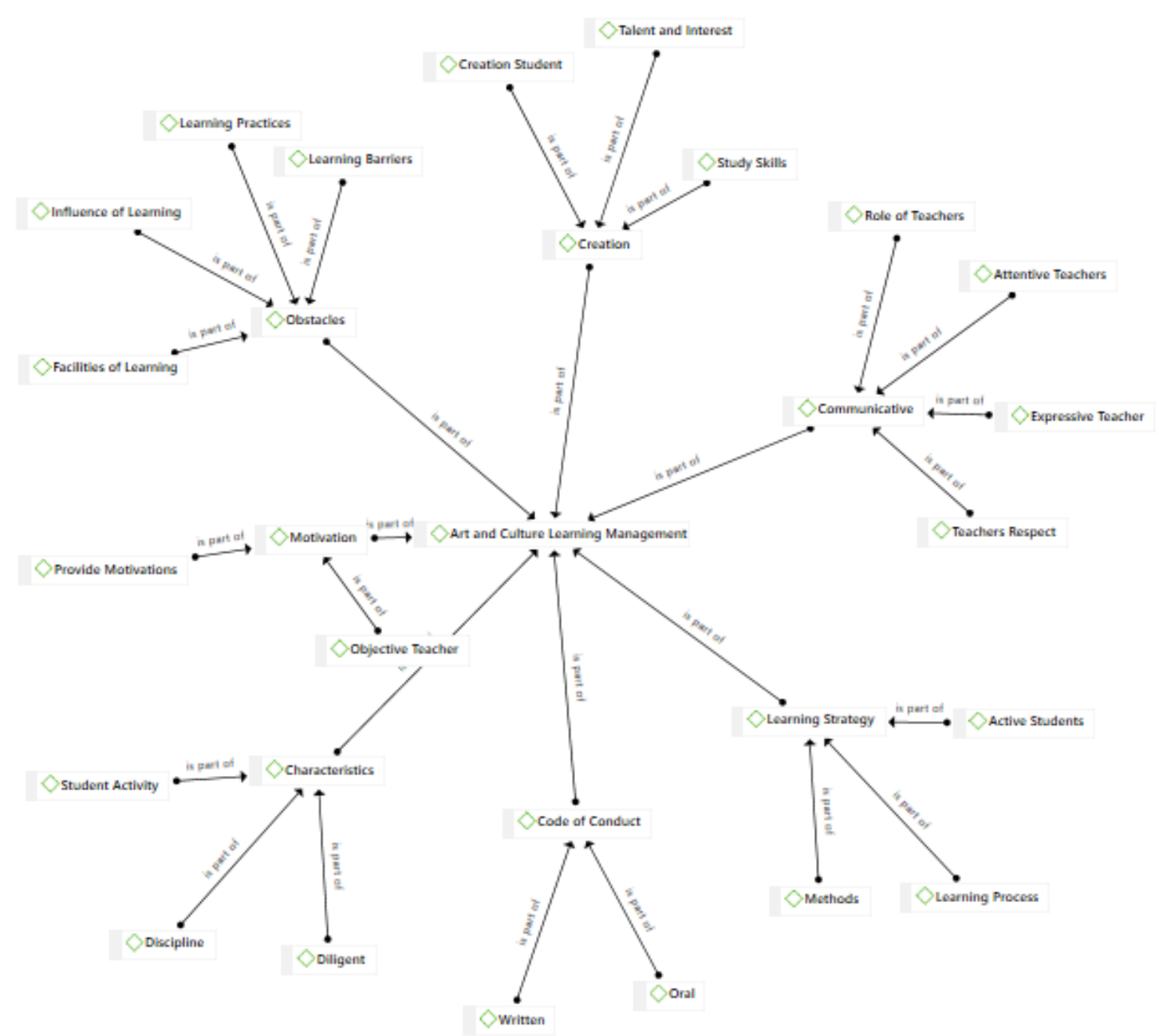

Figure 1 : Results of Qualitative Research Data Analysis with Atlas.ti 8.3

Figure 1 showed that: from the data analysis image above, it can be concluded that in the management of learning arts and culture that must be done with the presence of characteristics, creation, communication, motivation, learning strategies, and discipline. 
Class management in learning cultural art is one of teacher's duties that is never abandoned. The teacher needs to manage the class when carrying out their duties. Classroom management is intended to create a conducive learning environment for students so that the goals of teaching art and culture can be achieved effectively and efficiently (Priambudi, Mahmudah, \& Susatya, 2020). The activities of the cultural art teacher in the classroom include two main things, namely teaching and managing the class. Teaching activities are intended to directly encourage students to achieve goals. Class management activities aim to create and maintain a classroom atmosphere so that teaching activities can take place effectively and efficiently. Classroom management is a form of comfort in learning, an effort to manage classrooms and create comfortable places to study. To strive for this, the teacher as a manager in a classroom must be able to manage students, and organize school and classroom facilities for optimal education.

Classroom management is an important prerequisite for the implementation of good learning (Elistanto \& Mahmudah, 2020). In this case it is evidenced by the existence of a systematic learning plan in accordance with the technical curriculum 13 which is realized by the preparation of RPP activities. RPPs are prepared by cultural art teachers with regard to methods, media, learning resources and instruments in assessment. The preparation of the lesson plan is adjusted to the learning approach used, namely the scientific approach, learning activities using a scientific approach which includes: observing, asking, exploring, associating and communicating. RPP develops from the syllabus to direct the learning activities of students in an effort to achieve competency standards. After planning, the cultural art teacher carries out the learning.

Permendikbud RI No. 81A of 2013 concerning Implementation of the General Guidelines for Learning Curriculum explains that one form of the implementation of the curriculum is the assessment of learning outcomes. The implementation of learning art and culture at SMP Muhammadiyah 5 Yogyakarta uses an authentic assessment approach. Authentic assessment is the process of collecting information by teachers about the development and achievement of learning carried out by students through various techniques that are able to reveal, prove and show precisely that the learning objectives and competency abilities have actually been achieved.

Authentic assessment materials can be used to improve the learning process in accordance with educational assessment standards. The assessment is carried out through learning cultural art with daily tests, assignments and final semester tests. Daily tests are carried out at the end of the learning process in basic competencies and structured tasks related to the basic competencies being discussed. Meanwhile, the end of semester test is carried out at the end of the semester with the material being tested based on standard material in one semester. 


\section{Classroom Management in Learning Cultural Arts \\ Characteristics}

Characteristics are possessed by an individual. These characteristics exist in the individual's personality which drives how a person acts, acts, says and responds to something (Defitrika \& Mahmudah, 2021). Characteristics can be interpreted as basic values that build a person's personality, are well formed due to environmental influences (Maryam, 2018). Meanwhile, according to Michael Novak, characteristics are a compatible mixture of all goodness identified by religious traditions, literary stories, wise people and groups of common sense people in history (Thomas, 2012). A similar opinion was also conveyed by Wibowo (2013), that characteristics are ways of thinking and behaving that are characteristic of each individual to live and work together, both within the sphere of family, society, nation and state. From the opinion of the experts above, it can be concluded that a characteristic is something that is contained in an individual which is a characteristic of an individual's personality that is different from others in the form of attitudes, thoughts, behavior and character. These individual characteristics are useful for living and working together, both within the sphere of family, society, nation and state.

\section{Creation}

The result of the power of the brain or human intellect aims to produce an object from nothing into existence and is implemented in the form of work. The work may vary according to the abilities of each individual. According to the big dictionary, creation is the result of creation or imaginary power to create thoughts to produce something. Meanwhile, creation is an ability to create something new, as the ability to provide new ideas that can be applied in problem solving (Siregar \& Khayroiyah, 2019). Creation is one of the human abilities to integrate a stimulus with one's memories into something new. Based on some of the opinions above, it can be concluded that creation is the ability to create something new from each individual.

\section{Communicative}

Communicative is an attitude or viewpoint about a situation that is interconnected and easy to understand. According to the Indonesian dictionary, communicative is a state of interconnection. Communicative is part of a method which in the learning process prioritizes students' creativity to explore their abilities during learning (Iskandar, 2019). Communicative is part of a method that creates new innovations and strategies in the field of learning where skills are practiced in communication. With some of the opinions above, communicative can come up with strategies that have definite goals and can train students to be more active and creative. 


\section{Motivation}

Motivation is the process of influencing or encouraging from the outside to a person or work group so that they want to do something that has been determined (Tokan \& Imakulata, 2019). Motivation is the driving force from within to carry out activities in order to achieve their goals (Sudirman, 2014). Process motivation provides enthusiasm, direction, and behavior persistence. So with the motivation of students can proceed to become an encouragement for someone to carry out a series of activities that lead to the achievement of certain goals to meet some needs or produce something satisfying.

\section{Learning Strategy}

Learning strategy as a plan which contains a series of activities designed to achieve certain educational goals (Puspitorini, 2020). Educational strategy is a general component of a series of learning materials and procedures that will be used jointly by teachers and students during the learning process (Pancaningrum, 2016). The learning strategy is organizing lesson content, delivering lessons and managing learning activities using various learning resources used by teachers to support the creation of an effective and efficient learning process (Chu, Liu, \& Kuo, 2018). Then the learning strategy is a learning procedure in helping students' learning efforts, organizing learning experiences, arranging and planning teaching materials, in order to create a more effective and efficient learning process to achieve learning goals.

\section{Code of Conduct}

Order according to a large dictionary can be interpreted as rules, regulations, and arrangements that must be obeyed or implemented (Ministry of Education of Indonesia, 2008). Order means that there are arrangements and rules in relation to one part of another. Regulations are provisions that regulate daily school life and contain sanctions against violators. Thus, school discipline does not only help school programs, but also to support awareness and adherence to student responsibilities. One of the school's duties is to develop the human potential of children so that they are able to carry out the tasks of human life.

\section{Obstacles}

Constraints are a symptom of something that hinders a system from achieving higher performance. Constraints according to a large dictionary which means obstacles or obstacles with conditions that limit the achievement of something. There are several factors in learning constraints, from teachers, students, family and facilities (Putri, Hasratuddin, \& Syahputra, 2019). From some of the opinions above, it can be concluded that the constraints in learning are circumstances that limit, hinder or prevent the achievement of targets in learning, both human, material, and equipment facilities that hinder students' processes in developing skills and knowledge. 


\section{CONCLUSION}

Based on the discussion and research objectives, it can be concluded that there were efforts to implement class management in learning art and culture in improving student achievement at SMP Muhammadiyah 5 Yogyakarta. Teachers plan activities before implementing learning activities by preparing lesson plans, which greatly help teachers make it easier for them to prepare learning strategies properly. Class management is run and fully controlled by the teacher or homeroom teacher. Class management in learning cultural arts fully gives students confidence to manage their education.

Teachers do their job to assist and motivate students and direct students to meet competency standards, and the most important thing is to set a good example for students. In learning art and culture the teacher strives for contextual learning. Learning is not only theoretical waste, and returns it to students to condition a comfortable learning environment. The students who feels comfortable and create conditions in learning will know what they are learning something for.

From the classroom management that is carried out and the management of learning that is in favor of students, both involving students and the physical class, it has resulted in learning comfort for students, creating awareness based on a love of learning and high motivation and self-confidence of students to learn and realize what is learned. Achievements for education practitioners at SMP Muhammadiyah 5 are not just values in the form of numbers, but rather the achievement that makes students love to learn cultural art. Hence, it is hoped that it can benefit students personally and the environment around them.

\section{REFERENCES}

Chu, H. C., Liu, Y. M., \& Kuo, F. R. (2018). A mobile Sleep-management Learning System for Improving Students' Sleeping Habits by Integrating a Self-regulated Learning Strategy: Randomized Controlled Trial. JMIR mHealth and uHealth, 6(10), 1-14. https:/ / doi.org/10.2196/11557

Defitrika, F., \& Mahmudah, F. N. (2021). Development of Life Skills Education as Character Building. International Journal of Educational Management and Innovation, 2(1), 116-135. https:/ / doi.org/10.12928/ijemi.v2i1.3195

Elistanto, R., \& Mahmudah, F. (2020). Evaluasi Efektivitas Manajemen Pembelajaran Guru Produktif Otomotif SMK. Jurnal Studi Manajemen Pendidikan, 4(1), 102-115.

Hasbi, R. P., \& Mahmudah, F. N. (2020). Pengembangan Kurikulum Sekolah. Nidhomul Haq: Jurnal Manajemen Pendidikan Islam, 5(2), 1-6. https://doi.org/10.31538/ndh.v5i2.563

Iskandar, I. (2019). Prinsip Komunikasi Al-Qur'an dalam Menghadapi Era Media Baru. Jurnal Al-Fanar, 2(1), 55-74. https://doi.org/10.33511/alfanar.v2n1.55-74 
Maryam, S. (2018). Building Character Education Using Three Matra of Hasan Al-Banna'S Perspective in Pesantren. Jurnal Pendidikan Islam, 4(2), 51-62. https://doi.org/10.15575/jpi.v4i2.2422

Molchanova, V. S., \& Federation, R. (2019). Education and Financial Inclusion. An Empirical Study in Students of Higher Education. European Journal of Contemporary Education, 8(4), 810-818. https://doi.org/10.13187/ejced.2019.4.810

Pancaningrum, N. (2016). Strategi Pembelajaran: Taksonomi Bloom dalam Games Simulation Method di Tingkat Raudatul Athfal. Thufula: Jurnal Inovasi Pendidikan Guru Raudlatul Athfal, 4(1), 112-129.

Priambudi, P., Mahmudah, F. N., \& Susatya, E. (2020). Pengelolaan Kelas Industri di Sekolah Menengah Kejuruan. Jurnal Pendidikan Teknologi Kejuruan, 3(2), 87-97.

Puspitorini, F. (2020). Strategi Pembelajaran di Perguruan Tinggi pada Masa Pandemi Covid-19. Jurnal Kajian Ilmiah, 1(1), 99-106. https://doi.org/10.31599/jki.v1i1.274

Putri, S. K., Hasratuddin, H., \& Syahputra, E. (2019). Development of Learning Devices Based on Realistic Mathematics Education to Improve Students' Spatial Ability and Motivation. International Electronic Journal of Mathematics Education, 243-252. https://doi.org/10.29333/iejme/5729

Sholekah, F. F., \& Mahmudah, F. N. (2020). The Management Strategy of Headmaster in Efforts to Increase Self Awareness of School Residents of the Importance Environment. Journal of Educational Administration Research and Review, 4(1), 62-67.

Siregar, T. J., \& Khayroiyah, S. (2019). Pengaruh Model Pembelajaran Kooperatif Tipe Jigsaw terhadap Kemampuan Pemecahan Masalah Matematis Mahasiswa. Jurnal MathEducation Nusantara, 2(2), 150-154.

Sudirman. (2014). Interaksi Motivasi Belajar Mengajar. Depok: Raja Grafindo Persada.

Thomas, L. (2012). Mendidik Untuk Membentuk Karakter: Bagaimana Sekolah Dapat Memberikan Pendidikan Sikap Hormat dan Bertanggung Jawab. Jakarta: Bumi Aksara.

Tokan, M. K., \& Imakulata, M. M. (2019). The Effect of Motivation and Learning Behaviour on Student Achievement. South African Journal of Education, 39(1), 1-8. https://doi.org/10.15700/saje.v39n1a1510

Wibowo, A. (2013). Pendidikan: Strategi Membangun Karakter Bangsa Bearadaban. Yogyakarta: Pustaka Pelajar. 